\title{
Liver Transplantation for Hepatitis B Virus-related Hepatocellular Carcinoma in Hong Kong
}

\author{
Ka Wing $\mathrm{Ma}^{1}$, Kenneth Siu Ho Chok*1,2 , James Yan Yue Fung ${ }^{2,3}$ and Chung Mau Lo ${ }^{1,2}$ \\ ${ }^{1}$ Department of Surgery, The University of Hong Kong, Hong Kong, China; ${ }^{2}$ State Key Laboratory for Liver Research, \\ The University of Hong Kong, Hong Kong, China; ${ }^{3}$ Department of Medicine, The University of Hong Kong, Hong Kong, China
}

\begin{abstract}
Hepatocellular carcinoma (HCC) is the fifth most common cancer and the third most common cause of cancer-related deaths worldwide. Curative resection is frequently limited in Hong Kong by hepatitis B virus-related cirrhosis, and liver transplantation is the treatment of choice. Liver transplantation has been shown to produce superior oncological benefits, when compared to hepatectomy for HCC. New developments in the context of patient selection criteria, modification of organ allocation, bridging therapy, salvage liver transplantation and pharmaceutical breakthrough have improved the survival of HCC patients. In this article, we will share our experience in transplanting hepatitis B virus-related HCC patients in Hong Kong and discuss the recent progress in several areas of liver transplantation.
\end{abstract}

Citation of this article: Ma KW, Chok KSH, Fung JYY, Lo CM. Liver transplantation for hepatitis B virus-related hepatocellular carcinoma in Hong Kong. J Clin Transl Hepatol 2018;6(3): 283-288. doi: 10.14218/JCTH.2017.00058.

\section{Introduction}

Hong Kong is one of the endemic regions for hepatitis $B$ virus (HBV) infection. In a population surveillance report from the Health Ministry, $10.4 \%$ of males and $7.7 \%$ of the females were positive for HBV surface antigen. ${ }^{1}$ Chronic HBV infection has been the main etiology for the development of hepatocellular carcinoma (HCC) in this locality. ${ }^{2}$ The majority of HCC patients present at an advanced, inoperable stage; furthermore, development of HCC in the background of cirrhosis ${ }^{3}$ makes curative resection difficult.

Liver transplantation (LT) represents the last hope for this group of patients (Table 1 ). Since the landmark publication by

Keywords: Liver transplantation; Hepatitis B; Hepatocellular carcinoma; Review. Abbreviations: AFP, alpha fetoprotein; $\mathrm{CI}$, confidence interval; DDLT, deceased donor liver transplantation; ESLV, estimated standard liver volume; GW, graft weight; HBIG, hepatitis B immunoglobulin; HBV, hepatitis B virus; HCC, hepatocellular carcinoma; HIFU, high-intensity focused ultrasound; IVC, inferior vena cava; LT, liver transplantation; LDLT, living donor liver transplantation; m-TOR, mammalian target of rapamycin inhibitor; MELD, Model for End-Stage Liver Disease; OR, odds ratio; PIVKA-II, protein-induced vitamin K antagonist-II; pLT, primary liver transplantation; RVI, radiogenomic venous invasion; SBRT, stereotactic body radiotherapy; SFSS, small-for-size syndrome; TACE, transarterial chemoembolization; TTV, total tumor volume; UCSF, University of California, San Francisco.

Received: 22 August 2017; Revised: 9 January 2018; Accepted: 31 January 2018 *Correspondence to: Kenneth Siu Ho Chok, Department of Surgery, The University of Hong Kong, Hong Kong. Tel: +852-22553025, Fax: +852-28175475, E-mail: kennethchok@gmail.com
Mazzaferro et al. ${ }^{4}$ in 1996, LT has been regarded as an ideal treatment for $\mathrm{HCC}$, with 5 -year overall survival over $70 \%$. This encouraging result was subsequently demonstrated in many other centers around the world. At Queen Mary Hospital-the only liver transplant center in Hong Kong-the median survival after primary ( $p$ )LT for HBV-related HCC was 71.2 months (the $1-/ 5$-yr overall and disease-free survival rates were $95 \% / 85 \%$ and $80.5 \% / 77.8 \%$, respectively).

In order to reproduce and sustain this good oncological outcome, a well-designed LT protocol for HCC is indispensable. In this article, issues about patient selection criteria, the Model of End-Stage Liver Disease (MELD) exception scoring system and bridging therapy, living donor (LD)LT, small-for-size syndrome (SFSS), salvage LT, and postoperative antiviral and immunosuppressive therapies will be discussed.

Patient selection criteria and prediction of HCC recurrence

Like many other Asian regions, Hong Kong has a small donor pool, with a liver donation rate of about 4 in a million. ${ }^{5}$ This organ shortage is probably a result of poor acceptance of the brain death concept, insufficient government funding and cultural barriers. ${ }^{6}$ Careful patient selection and a tailor-made organ allocation system are essential to good utilization of this precious organ.

Different patient selection criteria have been advocated by different centers (Table 2). ${ }^{4,7-16}$ The majority of criteria still have a focus on tumor factors such as tumor size and number, with some fine adjustment. Our center has adopted the University of California, San Francisco (UCSF) criteria for patient selection for deceased donor DDLT. In recent years, new parameters such as alpha fetoprotein (AFP) level, ${ }^{14,16}$ protein-induced vitamin K antagonist-II (PIVKA-II), ${ }^{12,13}$ and degree of tumor differentiation ${ }^{15,16}$ have been proposed.

Pre-LT liver tumor biopsy is not routinely performed, due to anatomical reasons and concerns of tumor bleeding, seeding and risk of sampling error. Association between post-LT HCC recurrence and level of pre-LT AFP level has been demonstrated, and AFP is incorporated as a predicting parameter in some scoring systems (such as the RETREAT ${ }^{17}$ and MORAL ${ }^{18}$ scores) and nomograms. ${ }^{19}$ However, another study ${ }^{20}$ showed that the sensitivity of AFP for recurrent HCC was just around $59 \%$. In our center, around $20-30 \%$ of the HCC patients were nonsecretors of AFP; this fact might limit its application in patient selection.

PIVKA-II is currently not available in many centers, including ours. Yet, many studies have demonstrated high 
Table 1. Background information of liver transplantation in Hong Kong in 2016

\begin{tabular}{ll}
\hline $\begin{array}{l}\text { Total number of liver } \\
\text { transplantations, } n\end{array}$ & 72 \\
$\begin{array}{l}\text { Living donor liver } \\
\text { transplantation, } n \text { (\%) }\end{array}$ & $36(50)$ \\
$\begin{array}{l}\text { Deceased donor liver } \\
\text { transplantation, } n \text { (\%) }\end{array}$ & $36(50)$ \\
Common indications, \% & \\
• Cirrhosis & \\
• Acute/acute on chronic liver failure & 51.4 \\
• Hepatocellular carcinoma & 27.8 \\
OT time in min, mean (range) & 38.9 \\
• DDLT & \\
• LDLT & $431(270-929)$ \\
Blood loss in mL, mean (range) & $621(374-802)$ \\
& 3500 \\
Hospital stay in days, & $(300-18000)$ \\
mean (range) & $19(8-354)$ \\
All-complication rate, \% & \\
Hospital mortality, $n$ (\%) & 54.2 \\
\hline
\end{tabular}

sensitivity and specificity of PIVKA-II when used alone $e^{20-22}$ or in combination ${ }^{23,24}$ with AFP for the prediction of microvascular invasion and recurrence in HCC. Apart from biochemical markers, promising results in the prediction of microvascular invasion and $\mathrm{HCC}$ recurrence have been shown by using new radiological parameters, such as radiogenomic venous invasion (RVI ${ }^{25}$ and total tumor volume (TTV), ${ }^{26-28}$ on computed tomography scan and positron emission tomography scan using different isotope tracers (i.e. carbon-11 and 18fluoro-deoxy-glucose). ${ }^{29-31}$ Nonetheless, a majority of these results were from single-center series, and the cut-off values of parameters were not standardized. External validation with multicenter, multiethnic data is necessary before universal acceptance of these new predictive factors.

\section{MELD exception system and bridging therapy}

Patients who initially present with HCC beyond UCSF criteria are not eligible for DDLT in Hong Kong. Despite evidence showing that the survival outcomes of patients receiving LT after down-staging treatment for beyond-criteria HCC were comparable to those who received LT for within-criteria HCC, ${ }^{32-36}$ these studies had different patient inclusion criteria, modes of down-staging treatment, treatment end-points and rates of successful down-staging. Hence, the results should be interpreted with caution. In addition, there are only around 30-40 deceased-donor organs available each year in Hong Kong, and therefore it is not possible for the system to cater to the overwhelming number of down-staged HCC patients. As such, down-staging therapy is currently not implemented in Hong Kong.

The MELD score system was not intended for the estimation of HCC-related mortality, and most HCC patients have normal or low MELD scores. It has been reported that the drop-out rates for HCC patients on the LT wait list were $25 \%$ and $43 \%$ for first and second year respectively. ${ }^{15}$ Extra bonus score should be granted to HCC patients so as to adjust the estimated mortality risk associated with tumor progression and dissemination while waiting. Since October 2009, patients listed for DDLT who have HCCs that remain at stage 2 for 6 months after confirmation of stage 2 disease by imaging are assigned an arbitrary MELD score of 18 . An additional 2 points are added to the MELD score every 3 months if the disease

Table 2. Selection criteria for LT for HCC patients in different centers

\begin{tabular}{|c|c|c|c|c|}
\hline Criteria & Tumor size & $\begin{array}{l}\text { Tumor } \\
\text { number }\end{array}$ & Additional restriction & $\begin{array}{l}\text { Overall 5-yr } \\
\text { survival }\end{array}$ \\
\hline Mazzerfero $^{4}$ & $\begin{array}{l}<5 \mathrm{~cm} \\
<3 \mathrm{~cm}\end{array}$ & $\begin{array}{l}\text { Solitary } \\
\leq 3\end{array}$ & - & $74 \%(4-y r$ OS) \\
\hline UCSF $^{7}$ & $\begin{array}{l}<6.5 \mathrm{~cm} \\
<4.5 \mathrm{~cm} \\
\text { Total }<8 \mathrm{~cm}\end{array}$ & $\begin{array}{l}\text { Solitary } \\
\leq 3\end{array}$ & - & $75.2 \%$ \\
\hline University of Tokyo ${ }^{8}$ & $\leq 5 \mathrm{~cm}$ & $\leq 5$ & - & $75 \%$ \\
\hline Chang Guan University ${ }^{9}$ & $\begin{array}{l}6.5 \mathrm{~cm} \\
4.5 \mathrm{~cm}\end{array}$ & $\begin{array}{l}1 \\
\leq 3\end{array}$ & - & $90 \%$ \\
\hline $\operatorname{Asan}^{10}$ & $\leq 5 \mathrm{~cm}$ & $\leq 6$ & - & $82 \%$ \\
\hline Up-to-7 (Metroticket) (11 $^{11}$ & $\leq 7 \mathrm{~cm}$ & $\leq 7$ & $\begin{array}{l}\text { Numerical sum of tumor size and number } \\
\text { must be }<7\end{array}$ & $71.2 \%$ \\
\hline Kyoto University ${ }^{12}$ & $\leq 5 \mathrm{~cm}$ & $\leq 10$ & PIVKA-II $\leq 400 \mathrm{mAU} / \mathrm{mL}$ & $87 \%$ \\
\hline Kyushu University ${ }^{13}$ & $\leq 5 \mathrm{~cm}$ & Unlimited & PIVKA-II <300 mAU/mL & $83 \%$ \\
\hline Hangzhou ${ }^{14}$ & Total size $\leq 8 \mathrm{~cm}$ & Unlimited & $\begin{array}{l}\text { For total tumor }>8 \mathrm{~cm} \text {, histological grade } \\
\text { must be I or II and AFP must be } \leq 400 \mathrm{ng} / \mathrm{L}\end{array}$ & $72 \%$ \\
\hline Dubay $^{15}$ & Unlimited & Unlimited & $\begin{array}{l}\text { Only biopsy-confirmed poorly differentiated } \\
\text { HCC would be excluded }\end{array}$ & $72 \%$ \\
\hline Extended Toronto ${ }^{16}$ & Unlimited & Unlimited & $\begin{array}{l}\text { Presence of systemic HCC symptoms/poor } \\
\text { tumor grade/AFP > } 500 \mathrm{ng} / \mathrm{mL}\end{array}$ & $70 \%$ \\
\hline
\end{tabular}


remains at stage 2 . There is no upper limit for this bonus score granting; however, bonus granting will be withheld if the disease has progressed to stage III. Patients will be delisted if their disease has progressed to outside UCSF criteria. ${ }^{37}$

Various modes of bridging therapy, such as transarterial chemoembolization (TACE), image-guided local ablation, highintensity focused ultrasound (HIFU) and stereotactic body radiotherapy (SBRT), are available. ${ }^{38}$ In our center, TACE and SBRT are the two most commonly performed bridging therapies. The complete tumor necrosis rate was reported to be around $30 \% .^{39-43}$ Even if bridging therapy cannot improve the postLT survival or diminish the chance of HCC recurrence when complete pathologic response is not achieved, ${ }^{44}$ it serves to stop or slow down disease progression and maximize the chance of LT for wait-listed HCC patients.

\section{LDLT for HCC}

Competition between HCC and non-HCC patients for deceased-donor grafts in a tight donor pool has been a "zero-sum" game. LDLT is regarded as the solution to this situation. Given the low donor rate in Hong Kong, most of the LT cases are LDLTs. Conventionally, living donor graft was considered not suitable for patients with high MELD score, which is occasionally seen in HCC patients; however, our recent study suggested that living donor graft could work as well as deceased donor graft. ${ }^{45}$

With the use of living donor graft, which is a dedicated gift from a loved one, concerns about graft utility no longer exist. ${ }^{46,47}$ Patients with HCC beyond standard criteria could still be considered for LDLT. ${ }^{48}$ Results from our earlier case series $^{49}$ and a multicenter study ${ }^{50}$ have suggested that LDLT is associated with worse prognostic outcome when compared to DDLT. This worse outcome could be related to the "fast-tracking" effect and possible compromised vascular margin for posteriorly located HCC because the inferior vena cava (IVC) is not resected in total hepatectomy as in the case of DDLT. ${ }^{51}$

Recent studies were not able to confirm the oncological superiority of DDLT for $\mathrm{HCC}^{52,53}$ and this is probably related to the implementation of the MELD exception scoring system, which leads to a similar "fast-tracking" effect. Up to the moment, convincing evidence is still lacking to suggest superiority of either LDLT or DDLT.

\section{Conquering the small-for-size hurdle in LDLT for HCC}

Donor safety is the most concerning part of LDLT. Since the risk for a right lobe donor is 5 times higher $(0.5 \%$ in right lobe donor vs. $0.1 \%$ in left lobe donor), ${ }^{54}$ there is a recent trend of increasing use of left lobe graft in many centers, including ours. ${ }^{55-58}$ However, left lobe graft is often a small-for-size graft, especially when the recipient is of a size similar to or larger than the donor. This "left shifting" of living donor graft has shifted the risk from donors to recipients and increased the risk of SFSS. ${ }^{59,60}$ Despite this, good results have been reported from some centers. ${ }^{56,57}$

In order to reproduce this good outcome, accurate calculation of graft weight (GW) to estimated standard liver volume (ESLV) of the recipient is necessary preoperatively. A validated new formula using patients' body thickness and body weight for ESLV has been proposed by our center, in hopes of minimizing calculation error. ${ }^{61}$ Intraoperatively, in addition to the standardized steps, ${ }^{62,63}$ we need to shorten the warm ischemic time by expediting graft implantation. Portal venous flow and pressure are measured routinely by flowmeter and pressure transducer in case the GW/ESWL is less than $40 \% .{ }^{64,65}$ Portal venous modulation might be considered if the portal flow is high ( $>250 \mathrm{~mL} / \mathrm{min} / 100$ gm liver) and the portal venous pressure is over $10 \mathrm{mmHg} .{ }^{65,66}$ At our center, this is most commonly done by splenic artery ligation. ${ }^{66,67}$ Postoperatively, useful measures to avoid SFSS include strict fluid management in the intensive care unit, keeping central venous pressure at $5 \mathrm{cmH}_{2} \mathrm{O}$ by diuretics and albumin, and bed tilting up and right by 5 degrees.

\section{PLT and salvage LT}

Debates between the advocates of $\mathrm{pLT}^{68,69}$ and salvage $\mathrm{LT}^{70}$ have never ended since Majno et al. ${ }^{43}$ introduced the concept of salvage LT in 2000 . Bhangui et al. ${ }^{71}$ recently published an intention-to-treat analysis, comparing $130 \mathrm{HCC}$ patients receiving up-front liver resection with $366 \mathrm{HCC}$ patients listed for LT. The authors found that one-third of the patients in the up-front resection group developed nontransplantable recurrence, and both overall and disease-free survival rates were superior in the primary transplant group.

Instead of a universal approach of pLT, some centers advocate primary ${ }^{10,72} /$ prophylactic $\mathrm{LT}^{73}$ for patients with a higher likelihood of recurrence. In areas with organ shortage like Hong Kong, we resect whenever possible, as there are bound to be a significant proportion of patients who can be cured by resection. Moreover, this precludes the need for lifelong immunosuppression, rejection risk and donor risk in LDLT. Close surveillance is important to pick up recurrence at a transplantable stage.

\section{Postoperative viral and immunosuppressive therapy}

Adequate antiviral treatment after LT for HCC can reduce the chance of graft loss, hepatitis recurrence and HCC recurrence. ${ }^{74,75}$ In the past, due to the high incidence of drug resistance to lamivudine, hepatitis B immunoglobulin (HBIG) was added on, reducing the hepatitis recurrence rate to less than $5 \% .{ }^{76}$ Since the development a newer antiviral agent, monotherapy using entecavir has been shown to be effective and durable in achieving viral suppression and in preventing HBVrelated complications. ${ }^{77-79}$

For immunosuppressive therapy, tacrolimus has been the first-line medication for patients after LT since its development in the 1990s. ${ }^{80}$ However, there is the worry that the oncogenic property of this calcineurin inhibitor may predispose patients to HCC recurrence and metastasis. ${ }^{81,82}$ Apart from dose minimization, ${ }^{83}$ new agents such as sirolimus and everolimus have been shown to have antitumor properties. ${ }^{84}$

Studies from the United States ${ }^{85}$ and Canada ${ }^{86}$ have demonstrated better post-LT survival in patients with sirolimus. A recent case-controlled study published by Alamo et al., 87 comparing the antitumor efficacy of calcineurin inhibitor and mammalian target of rapamycin inhibitor (m-TOR), showed that the HCC recurrence rate and survival were significantly superior in patients who received either sirolimus or everolimus. In a meta-analysis published by Liang et al., ${ }^{88}$ use of a sirolimus-based immunosuppressive regimen was shown to be associated with prolonged overall survival (odds ratio $(\mathrm{OR})=2.47 ; 95 \%$ confidence interval $(\mathrm{CI}): 1.72-3.55)$ and decreased tumor recurrence $(\mathrm{OR}=0.42 ; 95 \% \mathrm{CI}$ : $0.21-$ 0.83 ), with no increase in frequency of acute rejection and hepatic artery thrombosis. A future randomized controlled 
trial is awaited to further define the role of $\mathrm{m}$-TOR in preventing $\mathrm{HCC}$ recurrence. Sirolimus should be avoided in the early postoperative period due to the risks of poor tissue healing and hepatic artery thrombosis.

\section{Conclusions}

LT is an ideal treatment for HCC as it removes both the tumor and the diseased liver. Careful patient selection and judicious use of the bonus MELD score improve the chance of waitlisted HCC patients. LDLT is equivalent to DDLT in terms of oncological outcomes as treatment for HCC patients. Salvage LT is an ideal approach as part of HCC management, especially in a region with organ shortage. Modern antiviral agents allow for daily oral administration, precluding the need for regular HBIG injection and at the same time providing excellent protection from HBV recurrence. Use of $\mathrm{m}$-TOR inhibitor might have a role in improving survival of selected HCC patients.

\section{Conflict of interest}

The authors have no conflict of interests related to this publication.

\section{Author contributions}

Manuscript drafting (KWM), design and supervision of the study (KSHC), provision of information from a hepatologist's perspective (JYYF), senior author, provision of intellectual and knowledge support, supervision of progress of the study (CML).

\section{References}

[1] Surveillance of viral hepatitis in Hong Kong -2010 update report. Hong Kong SAR: Department of Health, 2011.

[2] Poon D, Anderson BO, Chen LT, Tanaka K, Lau WY, Van Cutsem E, et al. Management of hepatocellular carcinoma in Asia: consensus statement from the Asian Oncology Summit 2009. Lancet Oncol 2009;10:1111-1118. doi: 10.1016/S1470-2045(09)70241-4.

[3] Llovet JM, Burroughs A, Bruix J. Hepatocellular carcinoma. Lancet 2003;362: 1907-1917. doi: 10.1016/S0140-6736(03)14964-1.

[4] Mazzaferro V, Regalia E, Doci R, Andreola S, Pulvirenti A, Bozzetti F, et al. Liver transplantation for the treatment of small hepatocellular carcinomas in patients with cirrhosis. N Engl J Med 1996;334:693-699. doi: 10. 1056/NEJM199603143341104.

[5] de Villa V, Lo CM. Liver transplantation for hepatocellular carcinoma in Asia. Oncologist 2007;12:1321-1331. doi: 10.1634/theoncologist.12-11-1321.

[6] Lo CM. Deceased donation in Asia: challenges and opportunities. Liver Transpl 2012;18:S5-S7. doi: 10.1002/lt.23545.

[7] Yao FY, Ferrell L, Bass NM, Watson J], Bacchetti P, Venook A, et al. Liver transplantation for hepatocellular carcinoma: expansion of the tumor size limits does not adversely impact survival. Hepatology 2001;33:13941403. doi: $10.1053 /$ jhep.2001.24563.

[8] Sugawara Y, Tamura S, Makuuchi M. Living donor liver transplantation for hepatocellular carcinoma: Tokyo University series. Dig Dis 2007;25:310312. doi: 10.1159/000106910.

[9] Concejero A, Chen CL, Wang CC, Wang SH, Lin CC, Liu YW, et al. Living donor liver transplantation for hepatocellular carcinoma: a single-center experience in Taiwan. Transplantation 2008;85:398-406. doi: 10.1097/TP. 0b013e3181622ff8.

[10] Lee SG, Hwang S, Moon DB, Ahn CS, Kim KH, Sung KB, et al. Expanded indication criteria of living donor liver transplantation for hepatocellular carcinoma at one large-volume center. Liver Transpl 2008;14:935-945. doi: 10. $1002 /$ It. 21445.

[11] Mazzaferro V, Llovet JM, Miceli R, Bhoori S, Schiavo M, Mariani L, et al. Predicting survival after liver transplantation in patients with hepatocellular carcinoma beyond the Milan criteria: a retrospective, exploratory analysis. Lancet Oncol 2009;10:35-43. doi: 10.1016/S1470-2045(08)70284-5.
[12] Takada $Y$, Uemoto $S$. Liver transplantation for hepatocellular carcinoma: the Kyoto experience. J Hepatobiliary Pancreat Sci 2010;17:527-532. doi: 10. 1007/s00534-009-0162-y.

[13] Taketomi A, Sanefuji K, Soejima Y, Yoshizumi T, Uhciyama H, Ikegami T, et al. Impact of des-gamma-carboxy prothrombin and tumor size on the recurrence of hepatocellular carcinoma after living donor liver transplantation. Transplantation 2009;87:531-537. doi: 10.1097/TP.0b013e3181943bee.

[14] Zheng SS, Xu X, Wu J, Chen J, Wang WL, Zhang M, et al. Liver transplantation for hepatocellular carcinoma: Hangzhou experiences. Transplantation 2008; 85:1726-1732. doi: 10.1097/TP.0b013e31816b67e4.

[15] DuBay D, Sandroussi C, Sandhu L, Cleary S, Guba M, Cattral MS, et al. Liver transplantation for advanced hepatocellular carcinoma using poor tumor differentiation on biopsy as an exclusion criterion. Ann Surg 2011;253:166-172. doi: 10.1097/SLA.0b013e31820508f1.

[16] Sapisochin G, Goldaracena N, Laurence JM, Dib M, Barbas A, Ghanekar A et al. The extended Toronto criteria for liver transplantation in patients with hepatocellular carcinoma: A prospective validation study. Hepatology 2016; 64:2077-2088. doi: 10.1002/hep.28643.

[17] Mehta N, Heimbach J, Harnois DM, Sapisochin G, Dodge JL, Lee D, et al. Validation of a risk estimation of tumor recurrence after transplant (RETREAT) score for hepatocellular carcinoma recurrence after liver transplant. JAMA Oncol 2017;3:493-500. doi: 10.1001/jamaoncol.2016.5116.

[18] Halazun KJ, Najjar M, Abdelmessih RM, Samstein B, Griesemer AD, Guarrera $\mathrm{JV}$, et al. Recurrence after liver transplantation for hepatocellular carcinoma: a new MORAL to the story. Ann Surg 2017;265:557-564. doi: 10.1097/SLA. 0000000000001966.

[19] Agopian VG, Harlander-Locke M, Zarrinpar A, Kaldas FM, Farmer DG, Yersiz $\mathrm{H}$, et al. A novel prognostic nomogram accurately predicts hepatocellular carcinoma recurrence after liver transplantation: analysis of 865 consecutive liver transplant recipients. J Am Coll Surg 2015;220:416-427. doi: 10. 1016/j.jamcollsurg.2014.12.025.

[20] Park MS, Lee KW, Kim H, Choi YR, Hong G, Yi NJ, et al. Usefulness of PIVKA-II after living-donor liver transplantation for hepatocellular carcinoma. Transplant Proc 2017;49:1109-1113. doi: 10.1016/j.transproceed.2017.03.017.

[21] Poté N, Cauchy F, Albuquerque M, Voitot H, Belghiti J, Castera L, et al. Performance of PIVKA-II for early hepatocellular carcinoma diagnosis and prediction of microvascular invasion. J Hepatol 2015;62:848-854. doi: 10. 1016/j.jhep.2014.11.005.

[22] Kim DY, Paik YH, Ahn SH, Youn YJ, Choi JW, Kim JK, et al. PIVKA-II is a useful tumor marker for recurrent hepatocellular carcinoma after surgical resection. Oncology 2007;72:52-57. doi: 10.1159/000111707.

[23] Kamiyama T, Yokoo $\mathrm{H}$, Kakisaka T, Orimo $\mathrm{T}$, Wakayama $\mathrm{K}$, Kamachi $\mathrm{H}$, et al. Multiplication of alpha-fetoprotein and protein induced by vitamin $\mathrm{K}$ absence-II is a powerful predictor of prognosis and recurrence in hepatocellular carcinoma patients after a hepatectomy. Hepatol Res 2015;45:E21-E31. doi: 10. 1111/hepr.12451.

[24] Lim TS, Kim DY, Han KH, Kim HS, Shin SH, Jung KS, et al. Combined use of AFP, PIVKA-II, and AFP-L3 as tumor markers enhances diagnostic accuracy for hepatocellular carcinoma in cirrhotic patients. Scand J Gastroenterol 2016;51:344-353. doi: 10.3109/00365521.2015.1082190.

[25] Banerjee S, Wang DS, Kim HJ, Sirlin CB, Chan MG, Korn RL, et al. A computed tomography radiogenomic biomarker predicts microvascular invasion and clinical outcomes in hepatocellular carcinoma. Hepatology $2015 ; 62$ : 792-800. doi: 10.1002/hep.27877.

[26] Lee YH, Hsia CY, Hsu CY, Huang YH, Lin HC, Huo TI. Total tumor volume is a better marker of tumor burden in hepatocellular carcinoma defined by the Milan criteria. World J Surg 2013;37:1348-1355. doi: 10.1007/s00268013-1978-9.

[27] Grat M, Kornasiewicz O, Hołówko W, Lewandowski Z, Zieniewicz K, Paczek L, et al. Evaluation of total tumor volume and pretransplantation $\alpha$-fetoprotein level as selection criteria for liver transplantation in patients with hepatocellular cancer. Transplant Proc 2013;45:1899-1903. doi: 10.1016/j.transproceed.2012.12.010.

[28] Hsu CY, Huang YH, Hsia CY, Su CW, Lin HC, Loong CC, et al. A new prognostic model for hepatocellular carcinoma based on total tumor volume: the Taipei Integrated Scoring System. J Hepatol 2010;53:108-117. doi: 10.1016/j. jhep.2010.01.038.

[29] Lee SD, Kim SH, Kim SK, Kim YK, Park SJ. Clinical impact of 18F-fluorodeoxyglucose positron emission tomography/computed tomography in living donor liver transplantation for advanced hepatocellular carcinoma. Transplantation 2015;99:2142-2149. doi: 10.1097/TP.0000000000000719.

[30] Kobayashi T, Aikata H, Honda F, Nakano N, Nakamura Y, Hatooka M, et al. Preoperative fluorine 18 fluorodeoxyglucose positron emission tomography/computed tomography for prediction of microvascular invasion in small hepatocellular carcinoma. J Comput Assist Tomogr 2016;40:524-530. doi: $10.1097 /$ RCT.0000000000000405.

[31] Cheung TT, Chan SC, Ho CL, Chok KS, Chan AC, Sharr WW, et al. Can positron emission tomography with the dual tracers [11 C]acetate and [18 F]fludeoxyglucose predict microvascular invasion in hepatocellular carcinoma? Liver Transpl 2011;17:1218-1225. doi: 10.1002/It.22362. 
[32] Chapman WC, Majella Doyle MB, Stuart JE, Vachharajani N, Crippin JS, Anderson $\mathrm{CD}$, et al. Outcomes of neoadjuvant transarterial chemoembolization to downstage hepatocellular carcinoma before liver transplantation. Ann Surg 2008;248:617-625. doi: 10.1097/SLA.0b013e31818a07d4.

[33] Ravaioli M, Grazi GL, Piscaglia F, Trevisani F, Cescon M, Ercolani G, et al. Liver transplantation for hepatocellular carcinoma: results of down-staging in patients initially outside the Milan selection criteria. Am J Transplant 2008 ; 8:2547-2557. doi: 10.1111/j.1600-6143.2008.02409.x.

[34] Barakat O, Wood RP, Ozaki CF, Ankoma-Sey V, Galati J, Skolkin M, et al. Morphological features of advanced hepatocellular carcinoma as a predictor of downstaging and liver transplantation: an intention-to-treat analysis. Liver Transpl 2010;16:289-299. doi: 10.1002/It.21994.

[35] Cillo U, Vitale A, Grigoletto F, Gringeri E, D'Amico F, Valmasoni M, et al. Intention-to-treat analysis of liver transplantation in selected, aggressively treated HCC patients exceeding the Milan criteria. Am J Transplant 2007; 7: 972-981. doi: 10.1111/j.1600-6143.2006.01719.x.

[36] Yao FY, Kerlan RK Jr, Hirose R, Davern TJ 3rd, Bass NM, Feng S, et al. Excellent outcome following down-staging of hepatocellular carcinoma prior to liver transplantation: an intention-to-treat analysis. Hepatology 2008;48:819-827. doi: 10.1002/hep.22412.

[37] Chan SC, Sharr WW, Chok KS, Chan AC, Lo CM. Wait and transplant for stage 2 hepatocellular carcinoma with deceased-donor liver grafts. Transplantation 2013;96:995-999. doi: 10.1097/TP.0b013e3182a339a7.

[38] She WH, Cheung TT. Bridging and downstaging therapy in patients suffering from hepatocellular carcinoma waiting on the list of liver transplantation. Transl Gastroenterol Hepatol 2016;1:34. doi: 10.21037/tgh.2016.03.04.

[39] Katz AW, Chawla S, Qu Z, Kashyap R, Milano MT, Hezel AF. Stereotactic hypofractionated radiation therapy as a bridge to transplantation for hepatocellular carcinoma: clinical outcome and pathologic correlation. Int J Radiat Oncol Biol Phys 2012;83:895-900. doi: 10.1016/j.ijrobp.2011.08.032.

[40] Oldhafer KJ, Chavan A, Frühauf NR, Flemming P, Schlitt HJ, Kubicka S, et al. Arterial chemoembolization before liver transplantation in patients with hepatocellular carcinoma: marked tumor necrosis, but no survival benefit? J Hepatol 1998;29:953-959. doi: 10.1016/S0168-8278(98)80123-2.

[41] Spreafico C, Marchianò A, Regalia E, Frigerio LF, Garbagnati F, Andreola S, et al. Chemoembolization of hepatocellular carcinoma in patients who undergo liver transplantation. Radiology 1994;192:687-690. doi: 10.1148/ radiology.192.3.8058934.

[42] Graziadei IW, Sandmueller H, Waldenberger P, Koenigsrainer A, Nachbaur K, Jaschke $W$, et al. Chemoembolization followed by liver transplantation for hepatocellular carcinoma impedes tumor progression while on the waiting list and leads to excellent outcome. Liver Transpl 2003;9:557-563. doi: 10. $1053 /$ jlts.2003.50106.

[43] Majno PE, Adam R, Bismuth $H$, Castaing D, Ariche A, Krissat J, et al. Influence of preoperative transarterial lipiodol chemoembolization on resection and transplantation for hepatocellular carcinoma in patients with cirrhosis. Ann Surg 1997;226:688-701; discussion 701-703.

[44] Agopian VG, Harlander-Locke MP, Ruiz RM, Klintmalm GB, Senguttuvan S, Florman SS, et al. Impact of pretransplant bridging locoregional therapy for patients with hepatocellular carcinoma within milan criteria undergoing liver transplantation: analysis of 3601 patients from the US multicenter HCC transplant consortium. Ann Surg 2017;266:525-535. doi: 10.1097/SLA. 0000000000002381.

[45] Chok KS, Fung JY, Chan AC, Dai WC, Sharr WW, Cheung TT, et al. Comparable short- and long-term outcomes in living donor and deceased donor liver transplantations for patients with model for end-stage liver disease scores $\geq 35$ in a hepatitis-B endemic area. Ann Surg 2017;265:173-177. doi: 10. 1097/SLA.0000000000001671.

[46] Akamatsu N, Sugawara Y, Kokudo N. Living donor liver transplantation for patients with hepatocellular carcinoma. Liver Cancer 2014;3:108-118. doi: $10.1159 / 000343866$.

[47] Song GW, Lee SG. Living donor liver transplantation. Curr Opin Organ Transplant 2014;19:217-222. doi: 10.1097/MOT.0000000000000088.

[48] Lee KW, Yi NJ, Suh KS. Section 5. Further expanding the criteria for HCC in living donor liver transplantation: when not to transplant: SNUH experience. Transplantation 2014;97 Suppl 8:S20-S23. doi: 10.1097/01.tp.0000446269. 20934.d3.

[49] Lo CM, Fan ST, Liu CL, Chan SC, Ng IO, Wong J. Living donor versus deceased donor liver transplantation for early irresectable hepatocellular carcinoma. Br J Surg 2007;94:78-86. doi: 10.1002/bjs.5528.

[50] Fisher RA, Kulik LM, Freise CE, Lok AS, Shearon TH, Brown RS Jr, et al. Hepatocellular carcinoma recurrence and death following living and deceased donor liver transplantation. Am J Transplant 2007;7:1601-1608. doi: 10.1111/j.1600-6143.2007.01802.x.

[51] Chan SC. Section 2. Small-for-size liver graft and hepatocellular carcinoma recurrence. Transplantation 2014;97 Suppl 8:S7-S10. doi: 10.1097/01.tp. 0000446266.42019 .28

[52] Chan SC, Fan ST, Lo CM, Liu CL, Wei WI, Chik BH, et al. A decade of right liver adult-to-adult living donor liver transplantation: the recipient mid-term outcomes. Ann Surg 2008;248:411-419. doi: 10.1097/SLA.0b013e31818584e6.
[53] Liang W, Wu L, Ling X, Schroder PM, Ju W, Wang D, et al. Living donor liver transplantation versus deceased donor liver transplantation for hepatocellular carcinoma: a meta-analysis. Liver Transpl 2012;18:1226-1236. doi: 10. 1002/lt.23490.

[54] Barr ML, Belghiti J, Villamil FG, Pomfret EA, Sutherland DS, Gruessner RW, et al. A report of the Vancouver Forum on the care of the live organ donor: lung, liver, pancreas, and intestine data and medical guidelines. Transplantation 2006;81:1373-1385. doi: 10.1097/01.tp.0000216825.56841.cd.

[55] Halazun KJ, Przybyszewski EM, Griesemer AD, Cherqui D, Michelassi F, Guarrera JV, et al. Leaning to the left: increasing the donor pool by using the left lobe, outcomes of the largest single-center North American experience of left lobe adult-to-adult living donor liver transplantation. Ann Surg 2016;264: 448-456. doi: 10.1097/SLA.0000000000001860.

[56] She WH, Chok KS, Fung JY, Chan AC, Lo CM. Outcomes of right-lobe and leftlobe living-donor liver transplantations using small-for-size grafts. World J Gastroenterol 2017;23:4270-4277. doi: 10.3748/wjg.v23.i23.4270.

[57] Soejima Y, Shirabe K, Taketomi A, Yoshizumi T, Uchiyama H, Ikegami T, et al. Left lobe living donor liver transplantation in adults. Am J Transplant 2012; 12:1877-1885. doi: 10.1111/j.1600-6143.2012.04022.x.

[58] Bathla L, Vargas LM, Langnas A. Left lobe liver transplants. Surg Clin North Am 2013;93:1325-1342. doi: 10.1016/j.suc.2013.09.003.

[59] Troisi R, de Hemptinne B. Clinical relevance of adapting portal vein flow in living donor liver transplantation in adult patients. Liver Transpl 2003;9: S36-S41. doi: 10.1053/jlts.2003.50200.

[60] Kiuchi T, Tanaka K, Ito T, Oike F, Ogura Y, Fujimoto $Y$, et al. Small-for-size graft in living donor liver transplantation: how far should we go? Liver Transpl 2003;9:S29-S35. doi: 10.1053/jlts.2003.50198.

[61] Ma KW, Chok KSH, Chan ACY, Tam HSC, Dai WC, Cheung TT, et al. A new formula for estimation of standard liver volume using computed tomographymeasured body thickness. Liver Transpl 2017;23:1113-1122. doi: 10.1002/It. 24807.

[62] Lo CM, Fan ST, Liu CL, Wong J. Hepatic venoplasty in living-donor liver transplantation using right lobe graft with middle hepatic vein. Transplantation 2003;75:358-360. doi: 10.1097/01.TP.0000046527.19422.3E.

[63] Fan ST, Lo CM, Liu CL. Technical refinement in adult-to-adult living donor liver transplantation using right lobe graft. Ann Surg 2000;231:126-131.

[64] Man K, Fan ST, Lo CM, Liu CL, Fung PC, Liang TB, et al. Graft injury in relation to graft size in right lobe live donor liver transplantation: a study of hepatic sinusoidal injury in correlation with portal hemodynamics and intragraft gene expression. Ann Surg 2003;237:256-264. doi: 10.1097/01.SLA.0000048976. 11824.67.

[65] Chan SC, Lo CM, Ng KK, Ng IO, Yong BH, Fan ST. Portal inflow and pressure changes in right liver living donor liver transplantation including the middle hepatic vein. Liver Transpl 2011;17:115-121. doi: 10.1002/It.22034.

[66] Troisi R, Cammu G, Militerno G, De Baerdemaeker L, Decruyenaere J, Hoste $\mathrm{E}$, et al. Modulation of portal graft inflow: a necessity in adult living-donor liver transplantation? Ann Surg 2003;237:429-436. doi: 10.1097/01.SLA. 0000055277.78876.B7.

[67] Lo CM, Liu CL, Fan ST. Portal hyperperfusion injury as the cause of primary nonfunction in a small-for-size liver graft-successful treatment with splenic artery ligation. Liver Transpl 2003;9:626-628. doi: 10.1053/jlts.2003.50081.

[68] Belghiti J, Cortes A, Abdalla EK, Régimbeau JM, Prakash K, Durand F, et al. Resection prior to liver transplantation for hepatocellular carcinoma. Ann Surg 2003;238:885-892; discussion 892-893. doi: 10.1097/01.sla.0000098621. 74851.65 .

[69] Cherqui D, Laurent A, Mocellin N, Tayar C, Luciani A, Van Nhieu JT, et al. Liver resection for transplantable hepatocellular carcinoma: long-term survival and role of secondary liver transplantation. Ann Surg 2009;250:738-746. doi: 10.1097/SLA.0b013e3181bd582b.

[70] Adam R, Azoulay D, Castaing D, Eshkenazy R, Pascal G, Hashizume K, et al. Liver resection as a bridge to transplantation for hepatocellular carcinoma on cirrhosis: a reasonable strategy? Ann Surg 2003;238:508-518; discussion 518-519. doi: 10.1097/01.sla.0000090449.87109.44.

[71] Bhangui P, Allard MA, Vibert E, Cherqui D, Pelletier G, Cunha AS, et al. Salvage versus primary liver transplantation for early hepatocellular carcinoma: do both strategies yield similar outcomes? Ann Surg 2016;264:155-163. doi: 10.1097/SLA.0000000000001442.

[72] Hwang S, Moon DB, Lee SG. Liver transplantation and conventional surgery for advanced hepatocellular carcinoma. Transpl Int 2010;23:723-727. doi: 10.1111/j.1432-2277.2010.01103.x.

[73] Sala M, Fuster J, Llovet JM, Navasa M, Solé M, Varela M, et al. High pathological risk of recurrence after surgical resection for hepatocellular carcinoma: an indication for salvage liver transplantation. Liver Transpl 2004; 10:1294-1300. doi: 10.1002/lt.20202.

[74] Fung J. Management of chronic hepatitis B before and after liver transplantation. World J Hepatol 2015;7:1421-1426. doi: 10.4254/wjh.v7.i10.1421.

[75] Lo CM, Cheung ST, Lai CL, Liu CL, Ng IO, Yuen MF, et al. Liver transplantation in Asian patients with chronic hepatitis B using lamivudine prophylaxis. Ann Surg 2001;233:276-281. doi: 10.1097/00000658-200102000-00018. 
[76] Yuen MF, Seto WK, Chow DH, Tsui K, Wong DK, Ngai VW, et al. Long-term lamivudine therapy reduces the risk of long-term complications of chronic hepatitis $B$ infection even in patients without advanced disease. Antivir Ther 2007; 12:1295-1303.

[77] Fung J, Wong T, Chok K, Chan A, Cheung TT, Dai JW, et al. Long-term outcomes of entecavir monotherapy for chronic hepatitis B after liver transplantation: Results up to 8 years. Hepatology 2017;66:1036-1044. doi: 10 . 1002/hep.29191.

[78] Fung J, Chan SC, Cheung C, Yuen MF, Chok KS, Sharr W, et al. Oral nucleoside/nucleotide analogs without hepatitis B immune globulin after liver transplantation for hepatitis B. Am J Gastroenterol 2013;108:942-948. doi: 10.1038/ajg.2013.111.

[79] Fung J, Cheung C, Chan SC, Yuen MF, Chok KS, Sharr W, et al. Entecavir monotherapy is effective in suppressing hepatitis B virus after liver transplantation. Gastroenterology 2011;141:1212-1219. doi: 10.1053/j.gastro. 2011.06.083.

[80] McAlister VC, Haddad E, Renouf E, Malthaner RA, Kjaer MS, Gluud LL. Cyclosporin versus tacrolimus as primary immunosuppressant after liver transplantation: a meta-analysis. Am J Transplant 2006;6:1578-1585. doi: 10 . 1111/j.1600-6143.2006.01360.x.

[81] Vivarelli M, Cucchetti A, Piscaglia F, La Barba G, Bolondi L, Cavallari A, et al. Analysis of risk factors for tumor recurrence after liver transplantation for hepatocellular carcinoma: key role of immunosuppression. Liver Transpl 2005;11:497-503. doi: 10.1002/It.20391.

[82] Hojo M, Morimoto T, Maluccio M, Asano T, Morimoto K, Lagman M, et al. Cyclosporine induces cancer progression by a cell-autonomous mechanism. Nature 1999;397:530-534. doi: 10.1038/17401.
[83] Vivarelli M, Bellusci R, Cucchetti A, Cavrini G, De Ruvo N, Aden AA, et al. Low recurrence rate of hepatocellular carcinoma after liver transplantation: better patient selection or lower immunosuppression? Transplantation 2002;74:1746-1751. doi: 10.1097/01.TP.0000039170.17434.33.

[84] Guba M, von Breitenbuch P, Steinbauer M, Koehl G, Flegel S, Hornung M, et al. Rapamycin inhibits primary and metastatic tumor growth by antiangiogenesis: involvement of vascular endothelial growth factor. Nat Med 2002;8 128-135. doi: 10.1038/nm0202-128.

[85] Zimmerman MA, Trotter JF, Wachs M, Bak T, Campsen J, Skibba A, et al. Sirolimus-based immunosuppression following liver transplantation for hepatocellular carcinoma. Liver Transpl 2008;14:633-638. doi: 10.1002/lt. 21420 .

[86] Toso C, Meeberg GA, Bigam DL, Oberholzer J, Shapiro AM, Gutfreund K, et al. De novo sirolimus-based immunosuppression after liver transplantation for hepatocellular carcinoma: long-term outcomes and side effects. Transplantation 2007;83:1162-1168. doi: 10.1097/01.tp.0000262607. 95372.e0.

[87] Alamo JM, Bernal C, Marín LM, Suárez G, Serrano J, Barrera L, et al. Antitumor efficacy of mammalian target of rapamycin inhibitor therapy in liver transplant recipients with oncological disease: a case-control study. Transplant Proc 2012;44:2089-2092. doi: 10.1016/j.transproceed.2012. 07.079 .

[88] Liang $W$, Wang $D$, Ling $X$, Kao AA, Kong $Y$, Shang $Y$, et al. Sirolimusbased immunosuppression in liver transplantation for hepatocellular carcinoma: a meta-analysis. Liver Transpl 2012;18:62-69. doi: 10.1002/lt. 22441. 